Prosiding Seminar Nasional Teknologi Informasi dan Kedirgantaraan : Transformasi Teknologi untuk Mendukung Ketahanan Nasional, Yogyakarta, 13 Desember 2018

SENATIK 2018, Vol. IV, ISBN 978-602-52742-0-6

DOI: http://dx.doi.org/10.28989/senatik.v4i0.258

\title{
APPLICATION OF LINEAR REGRESSION ANALYSIS MODEL ON EARLY WARNING SYSTEM FOR INEFFICIENCY OF ELECTRICITY USAGE
}

\author{
Rahman Indra Kesuma ${ }^{1)}$, Hafiz Budi Firmansyah ${ }^{2)}$, Mahardika Yoga Darmawan ${ }^{3)}$ \\ ${ }^{1,2}$ Informatics Engineering Dept., Institut Teknologi Sumatera \\ ${ }^{3}$ Physics Department, Institut Teknologi Sumatera \\ Lampung Selatan, Indonesia \\ Email : rahman.indra@if.itera.ac.id
}

\begin{abstract}
Recently the Indonesian people often get inefficiency of electricity usage. On the other side, in Indonesia, the electricity is mostly produced from steam power plant, which require fuel from non-renewable natural resources. So the highness of demand and the occurrence of inefficiency the electricity usage can increase the consumption of natural resource and the air pollution. Therefore, an early warning system are proposed in this study, become one of the various solution than can increase awareness of the people in efficiency of electricity usage. This system requires the input data of electricity usage in the last 6 months, that will be formed the electricity usage trend from each user using linear regression analysis. Furthermore, this trend will predict the electricity usage for next month, this is used as the limit to give the warning from the system. The outcome from this study is the system that can provide a warning to users if their electricity usage run over the certain limits.
\end{abstract}

Keyword: early warning system, inefficiency of electricity usage, linear regression analysis

\section{Introduction}

The electricity become secondary needs of the Indonesian peoples after their needs such as clothing, food and home. Even if there is the electricity lack in certain period of time, many people's activities cannot run well. This situation has worsen by the growing of the electricity demand from the people. But on the other side, we known that the electricity energy cannot be directly found from nature. The electricity energy is made by a transformation from one kind energy to other energy.

Until on the end of 2015, Indonesia can generate electricity power to $233,981.98$ GWh and had 61,167,980 customers with $92.54 \%$ were customers that consumption electricity power for household [1]. Now, the electricity energy in Indonesia is produced mostly from steam power plants, that is equal to $41.35 \%$. This type of power plant requires fuel from non-renewable natural resources (coal and petroleum). The combustion process from this power plant will produce smoke that can pollute the air.

This condition is worsen by the lack of awareness from Indonesian people in electricity usage. Many people often get inefficiency from their electricity usage. This is supported by the experimental results from previous studies, which explained that during 1990-2010 there was an inefficiency on electricity usage in the general and household categories [2]. So that it requires a hard work from power plants to consume more fuel, in order to meet the growing of electricity power needs. In addition, the air pollution will also increase. 
Therefore, a solution was proposed in this research as an effort to reduce this bad conditions, by trying to reduce the level of inefficiency from the electricity usage. An early warning system is used by applies the concept of linear regression analysis models to create trend data and predictions of electricity power usage from each customer.

\section{Literature Review}

Many research that are related to the early warning system is still evolve, which initially the early warning system is used for the needed of natural disasters, but now the early warning system has also been implemented to prevent damage and failure of a work system. In this chapter some previous studies will be discussed that are related to the development of early warning systems for the problems (besides for give warning of natural disasters), and including time series data analysis which is method used in this study.

The main motivation in this study is the inefficiency of electricity usage that occurs in several regions in Indonesia. The research that has been done by Kurdi, get the results of inefficient usage in specific area, the Banten education and training service, there are tendency of inefficiency usage in the category of strong enough, with a percentage value is $60 \%$ [3]. In other side, Listyarini with her research in the DKI Jakarta get the results that the optimal usage of the electricity power for 2006 in DKI Jakarta was only around $39.18 \%$ from the overall production [4]. This illustrates that the electricity usage in DKI Jakarta is very inefficient.

Early warning systems should be used as a solution to reduce the inefficiency in the electricity usage. The application of this system has also been used in handling a financial crisis problems and risk analysis of a bank. In Gramlich's et al studies, which use it on policies that have been designed to analyze conditions in the past that will be related to future systemic risks [5]. In other studies, Stanciu and Percic et al in their respective research found that early warning systems are very useful to help maintain global growth and financial stability by considering past events, so as to predict the occurrence of a crisis within a certain period of time [6] [7].

In this research, we not only apply the concept of the early warning system to prevent the occurrence of inefficiency in electricity usage, but also use time series data analysis, that is the linear regression analysis model. Linear regression, according to Lind et al and Shumway with Stoffer, has a objective as a measuring tool to determine whether or not there is a correlation between variables [8] [9]. In time series data analysis, which is the value from a variable based on a certain period of time and periodically, linear regression can be used to create models with dynamic data given.

\section{Theoretical Approaches}

Implementation of this research requires an understanding of concepts that can make this research run well. The understanding that is related to the early warning system and linear regression analysis is a fundamental requirement in this study.

\subsection{Early Warning System}

The early warning system is an integrated system that has a purpose to monitoring, data collection, analysis, interpretation and communication of data that can be monitored [10]. The data that has been obtained can be used to make initial decisions to protect the health of the public or the environment, and to minimize the concerns and inconveniences of the people. Current technological advances support the use of early warning systems that allow for monitoring of pollution or environmental degradation phenomena in real-time. Essentially, this activity detect how adverse conditions are, and then make predictions that are possible to avoid these. 


\subsection{Linear Regression Analysis}

In this study, linear regression analysis are used to create trend data model from the electricity usage of each customer. Trend data is a dynamic state of data (can rise and fall) over time. Here is a linear regression formula that is used

$$
\hat{y}=a+b t
$$

where $\hat{y}$ is the time series data to be estimated (the electricity usage data in the following month), $t$ is the time variable (the month that will be predicted for the electricity usage), $a$ and $b$ are constants and coefficients. While the values $a$ and $b$ can be obtained from the following formula:

$$
\begin{gathered}
a=\bar{y}-b \bar{t} \\
\bar{y}=\frac{\sum y}{n} \text { and } \bar{t}=\frac{\sum t}{n} \\
b=\frac{\sum t y-\frac{\sum t \sum y}{n}}{\sum t^{2}-\frac{\left(\sum t\right)^{2}}{n}}
\end{gathered}
$$

where $y$ is the amount of electricity used in $t$ month. Whereas $n$ is the amount of data from the costumer's electricity usage that will be considered to predict the electricity usage in the next month. For example, if we want to know the predictions of electricity usage in the next month from one customer, that has electricity usage in the last 6 months, such as 13070, 13216, 13415, 13604, 13773 and 13862 in $\mathrm{kWh}$ units, the following calculation are

Table 1. Initial Calculation in Linear Regression

\begin{tabular}{|c|c|c|c|}
\hline Month $(\boldsymbol{t})$ & $\begin{array}{c}\text { Electricity } \\
\text { Usage }(\boldsymbol{y})\end{array}$ & $(\boldsymbol{t} * \boldsymbol{y})$ & $\boldsymbol{t}^{\mathbf{2}}$ \\
\hline 1 & 13070 & 13070 & 1 \\
\hline 2 & 13216 & 26432 & 4 \\
\hline 3 & 13415 & 40245 & 9 \\
\hline 4 & 13604 & 54416 & 16 \\
\hline 5 & 13773 & 68865 & 25 \\
\hline 6 & 13862 & 83172 & 36 \\
\hline $\boldsymbol{\Sigma}=\mathbf{2 1}$ & $\mathbf{\Sigma}=\mathbf{8 0 9 4 0}$ & $\mathbf{\Sigma}=\mathbf{2 8 6 2 0 0}$ & $\boldsymbol{\Sigma}=\mathbf{9 1}$ \\
\hline
\end{tabular}

After that calculation are obtained, so we can get the value from $\bar{y}, \bar{t}$, and $b$ that can be seen in equations (5), (6) and (7)

$$
\begin{gathered}
\bar{y}=\frac{\sum y}{n}=\frac{80940}{6}=13490 \\
\bar{t}=\frac{\sum t}{n}=\frac{21}{6}=3,5 \\
b=\frac{\sum t y-\frac{\sum t \sum y}{n}}{\sum t^{2}-\frac{\left(\sum t\right)^{2}}{n}}=\frac{286200-\frac{21 * 80940}{6}}{91-\frac{21^{2}}{6}}=166,29
\end{gathered}
$$

Furthermore, we also can get the values of $a$ and the linear regression formula as seen in equations (8) and (9)

$$
\begin{gathered}
a=\bar{y}-b \bar{t}=13490-166,29 * 3,5=12908 \\
\hat{y}=a+b t=12908+166,29 * t
\end{gathered}
$$


Finally, to get the electricity usage in the $7^{\text {th }}$ month, we can use the equation (9) by give $t$ value with 7 . Then the prediction of electricity usage in the next month are $14072 \mathrm{kWh}$.

\section{Experimental Setting}

The data that is used in this research are divided into two categories, which is primary data and secondary data. Primary data is the electricity usage sample data from 194 customers that is scattered in 14 districts/cities in Lampung Province which were randomly sampled. The electricity usage data contains the electricity power data $(\mathrm{kWh})$ that are used on each month, over the last 6 months. The distribution of customer data from the primary data used can be seen in Table 2, as well as the example of data table representation of that data can be observed in Table 3.

Table 2. The Distribution of Primary Data

\begin{tabular}{|c|l|c|}
\hline NO & \multicolumn{1}{|c|}{ DISTRICT / CITY } & DATA \\
\hline 1 & Lampung Selatan & 23 \\
\hline 2 & Lampung Tengah & 25 \\
\hline 3 & Lampung Utara & 13 \\
\hline 4 & Lampung Barat & 7 \\
\hline 5 & Tulang Bawang & 3 \\
\hline 6 & Tanggamus & 10 \\
\hline 7 & Lampung Timur & 12 \\
\hline 8 & Way Kanan & 4 \\
\hline 9 & Pesawaran & 5 \\
\hline 10 & Pringsewu & 10 \\
\hline 11 & Mesuji & 2 \\
\hline 12 & Tulang Bawang Barat & 71 \\
\hline 13 & Bandar Lampung & 4 \\
\hline 14 & Metro & $\mathbf{1 9 4}$ \\
\hline \multicolumn{2}{|c|}{ TOTAL } \\
\hline
\end{tabular}

Table 3. The Data Table Representation of Primary Data

\begin{tabular}{|c|c|l|l|c|c|c|c|c|c|}
\hline No & Customer ID & Customer Name & District / City & kWh 1 & kWh 2 & kWh 3 & kWh 4 & kWh 5 & kWh 6 \\
\hline 1 & $171201486 X X X$ & Likman Efendi MS & Lampung Selatan & 13070 & 13216 & 13415 & 13604 & 13773 & 13862 \\
\hline 2 & $171201638 X X X$ & Sugianto GK & Lampung Selatan & 22240 & 22279 & 22348 & 22421 & 22499 & 22572 \\
\hline 3 & $171201821 X X X$ & Rachmad Sudjut & Lampung Selatan & 24232 & 24418 & 24627 & 24757 & 24985 & 25121 \\
\hline 4 & $171100276 X X X$ & Yahya Heryana & Lampung Selatan & 17665 & 17784 & 17912 & 18033 & 18160 & 18288 \\
\hline 5 & $171120276 X X X$ & Perum Permata Asri & Lampung Selatan & 16085 & 16349 & 16618 & 16929 & 17240 & 17528 \\
\hline 6 & $171510200 X X X$ & Sari Wijaya & Lampung Selatan & 21775 & 21897 & 22031 & 22161 & 22300 & 22458 \\
\hline 7 & $171120107 X X X$ & Haryono & Lampung Selatan & 13492 & 13565 & 13634 & 13709 & 13794 & 13877 \\
\hline 8 & $171201921 X X X$ & Sholihin & Lampung Selatan & 6262 & 6385 & 6511 & 6615 & 6712 & 6824 \\
\hline 9 & $171300157 X X X$ & Ibnu Hajar, SH & Lampung Selatan & 8241 & 8477 & 8675 & 8874 & 9106 & 9338 \\
\hline 10 & $171300130 X X X$ & Nasrul & Lampung Selatan & 24003 & 24157 & 24287 & 24414 & 24558 & 24702 \\
\hline$\ldots$ & $\ldots$ & $\ldots$ & $\ldots$ & $\ldots$ & $\ldots$ & $\ldots$ & $\ldots$ & $\ldots$ \\
\hline
\end{tabular}


While to secondary data are used photo from the electricity usage recording machine of several PLN customers, which will produce the daily electricity usage data from that photo.

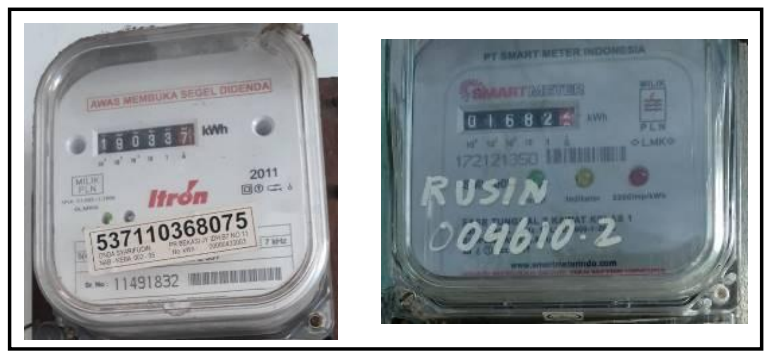

Figure 1. Example of the electricity usage recording machine

In the implementation of the early warning systems development, this studies use PHP and Python programming languages that are combined with the Mysql Database. The system that has been developed are implemented on computer devices with minimum specifications of Intel ${ }^{\circledR}$ Core $^{\mathrm{TM}}$ i3-4150 Processor (3.50 GHz, 3M Cache), Memory 2GB DDR3, and 500GB Serial ATA (7200RPM).

\section{Result and Discussion}

The work flow of the early warning system developed is to use the daily electricity usage data for each customer to predict the usage in the next month. The prediction data will be divided by the number of days (adjusted from the predicted month) to get a limit on the daily electricity usage. This electricity usage limitation that will trigger to giving of notifications if there is increasing significantly in electricity usage with a specified threshold. An outline of that work flow from the system developed in this study can be seen in Figure 2 .

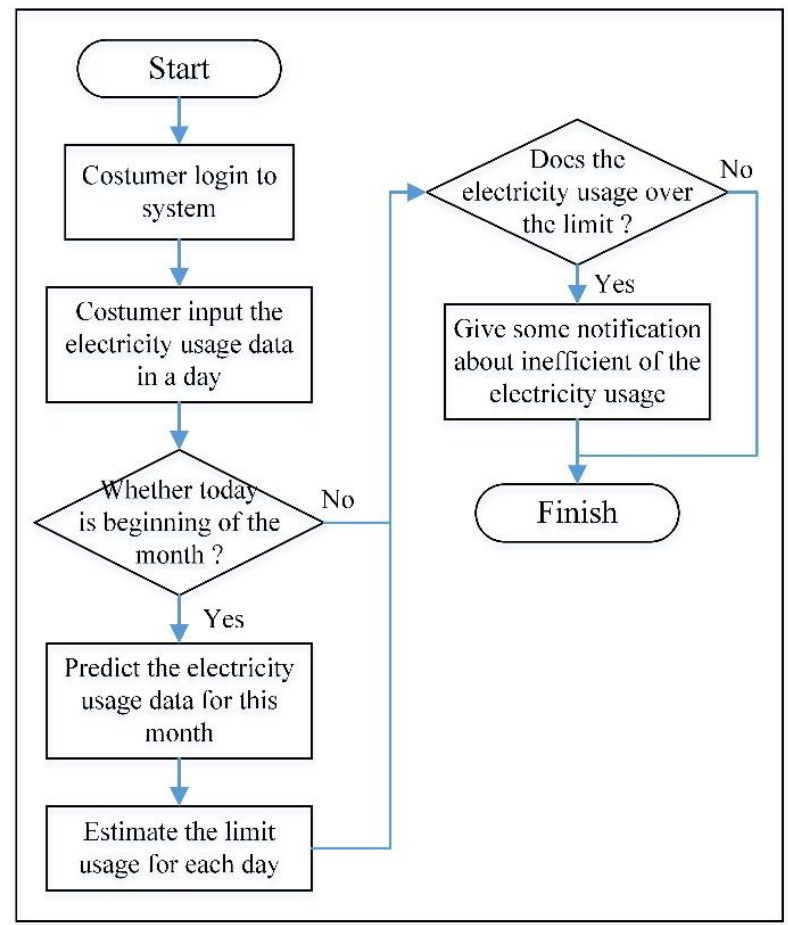

Figure 2. The work flow of early warning system

The early warning system development by applying the concept of linear regression analysis has four main modules, such as data management (customer and alert notification), input the daily electricity usage data, conversion of image into numeric digits, and the daily 
electricity usage track records from each customer. The customer data management module has the purpose to view detailed info, verify the account activeness and deactivate account. While the notification management module is to manage the information/notification that will be issued by the system if the customer has exceeded the electricity usage limitation. Figure 3 provides a view of the customer data and alert notifications management module.

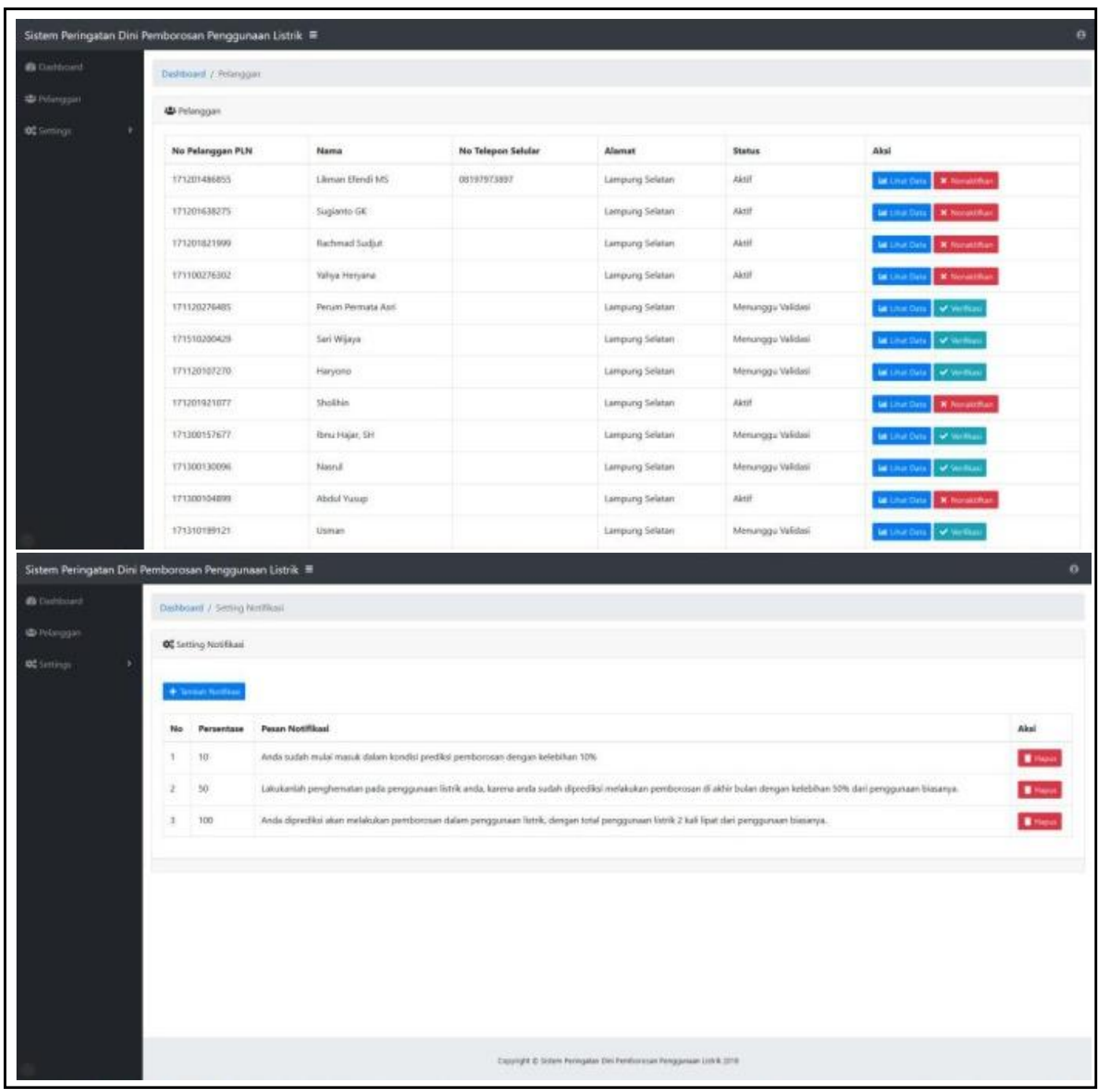

Figure 3. Interface of data management module

The data input module for the daily electricity usage, is still done manually, by uploading a electricity usage recording machine photo, which has been cut in the electricity meter digit number information section, and by entering the information needed by the system. Display of data input module for the daily electricity usage can be seen in Figure 4. 


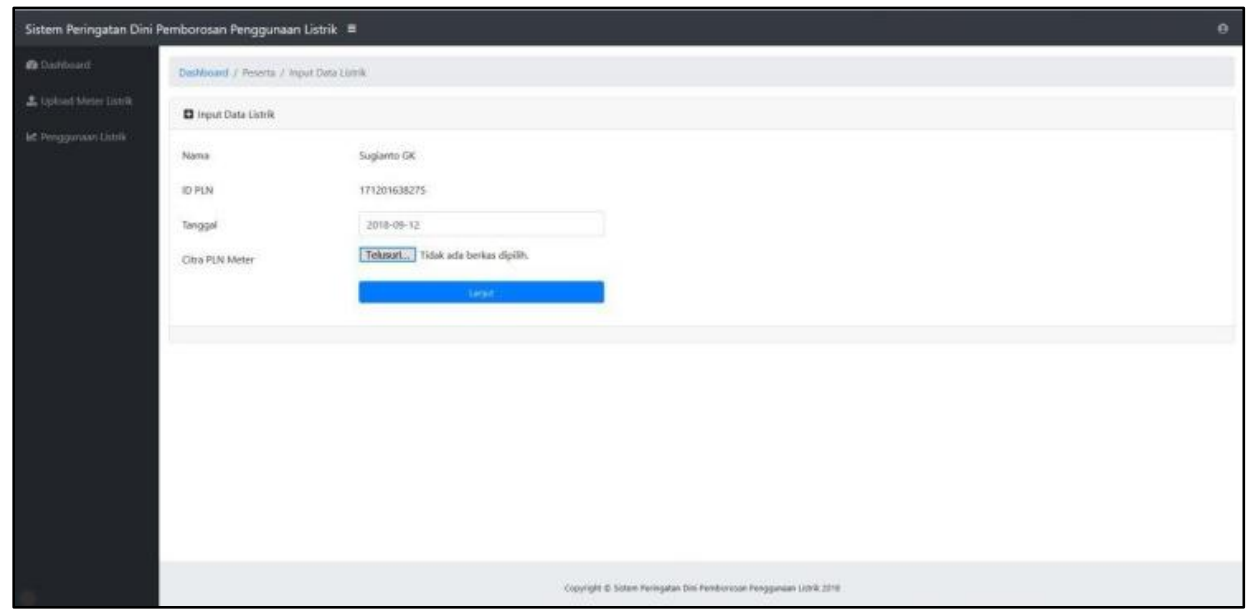

Figure 4. Interface of the daily electricity usage data input module

At the end there is a process of converting image data into numeric digits as shown in Figure 5, as well as a track record of the daily electricity usage from each customer in a certain month in Figure 6.

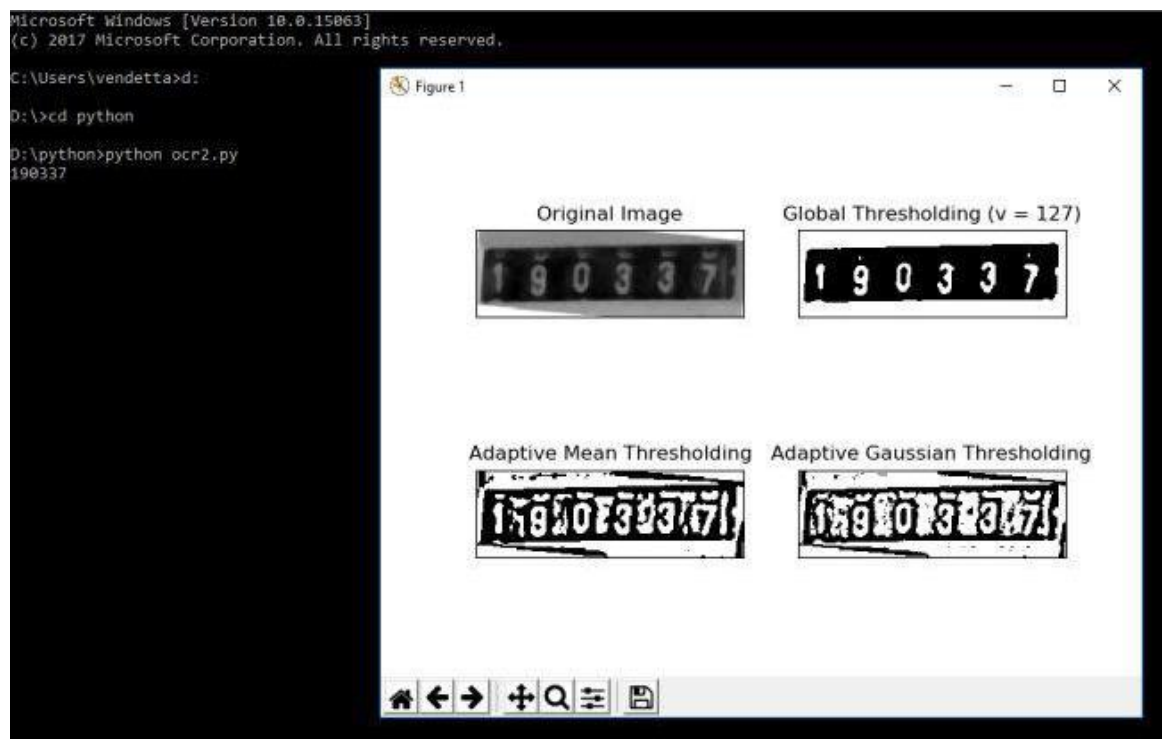

Figure 5. Example of converting data

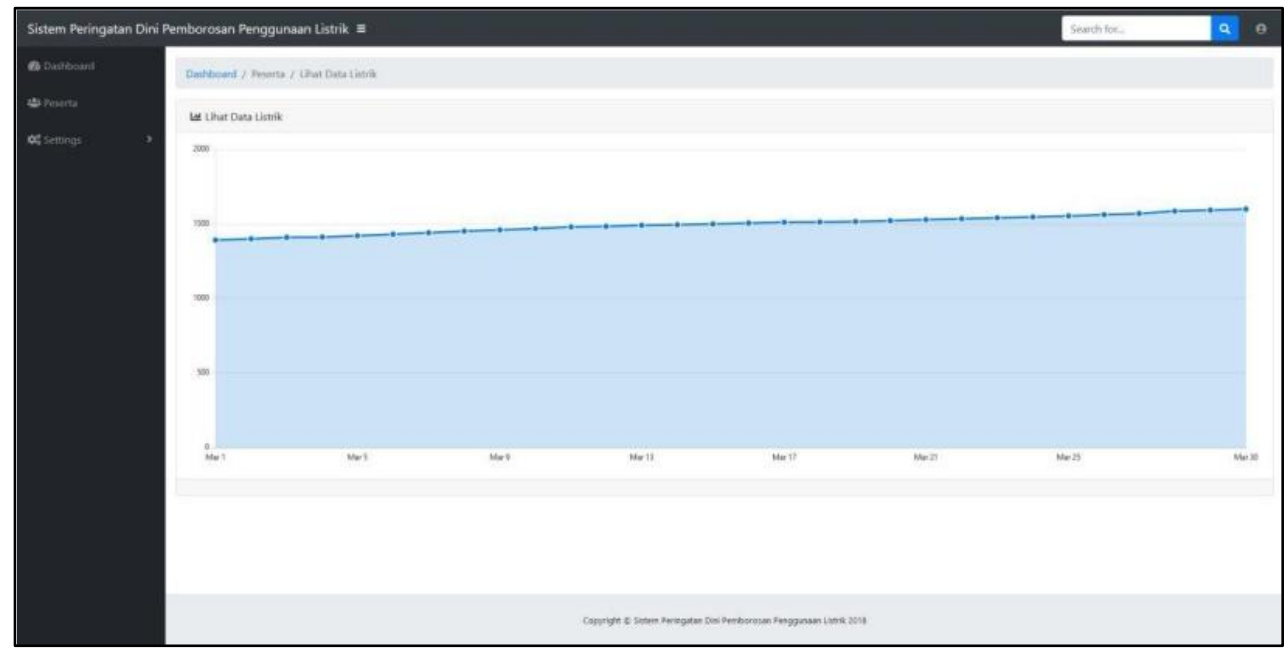

Figure 6. Interface of the daily electricity usage track record 
The result testing is done by first we observe and analyze the value of input, output and specification. In this studies, we use error guessing where we make a list of possible mistakes and proceed the testing whilst observe and analyze the list. The result of testing is shown in the following table:

Table 4. Result Testing

\begin{tabular}{|l|l|l|}
\hline \multicolumn{1}{|c|}{ Testing } & \multicolumn{1}{c|}{ Detail } & \multicolumn{1}{c|}{ Info } \\
\hline $\begin{array}{l}\text { Application } \\
\text { Function }\end{array}$ & $\begin{array}{l}\text { a. } \begin{array}{l}\text { Data processing (create, } \\
\text { read, update, and delete) } \\
\text { b. The use of data relation } \\
\text { c. Alert notification in the } \\
\text { electricity usage }\end{array} \\
\text { d. Process data input }\end{array}$ & Good \\
Application & $\begin{array}{l}\text { a. } \text { The bound of input } \\
\text { character }\end{array}$ & Not Good \\
Interface & $\begin{array}{l}\text { The bound of the type of } \\
\text { input character }\end{array}$ & Good \\
& c. Respond to application & Good \\
\hline
\end{tabular}

\section{Conclusion and Future Work} are:

Based on the experimental results that has been obtained, the following conclusions

1) This study are successfully implement a linear regression analysis model to develop an early warning system for inefficiency of electricity usage.

2) This system has limitations, such as the image file or electricity usage recording machine photo must have been normalized before being inserted into the system, by only taking the area that displays the digit number $\mathrm{kWh}$ of electricity usage.

With the limitations are obtained from the experimental results, the future work is:

1) Adding the facility of sending information to the customer's personal number when there is an increasing of the electricity usage that exceeds the usage limitation.

2) Using an embedded system to obtain information about the daily electricity usage as a substitute for manual data input such as the electricity usage recording machine through the website.

\section{Acknowledgement}

The research was supported by The Directorate of Research and Community Service, The Directorate General of Strengthening for Research and Development (The Ministry of Research, Technology, \& Higher Education - Republic of Indonesia). We would like to thank our colleagues from Institut Teknologi Sumatera who provided insight, expertise or cooperation in this research.

\section{References}

[1] Triboesono, A. (2016). Statistik Ketenagalistikan 2015. Dirjen Ketenaga-listrikan ESDM

[2] Parahate, F. X. (2013). Analisis Permintaan dan Efisiensi Energi Listrik di Indonesia tahun 1990-2010. Jurnal Ilmu Ekonomi. 
[3] Kurdi, M. (2016, Januari-Maret). Hemat Energi Listrik: Studi Kasus di Badan Diklat Provinsi Banten. Jurnal Lingkaran Widyaiswara. (Vol. 3, pp. 47-52)

[4] Listyarini, S. (2012). Penggunaan Goal Programming Untuk Menganalisis Pemborosan Listrik Di DKI Jakarta. Jurnal Sains MIPA Universitas Lampung, 6(3).

[5] Gramlich, D., Miller, G., Oet, M. V., \& Ong, S. J. (2010). Early warning systems for systemic banking risk: critical review and modeling implications.

[6] Stanciu, C. (2012). THE FINANCIAL CRISIS AND THE EARLY WARNING SYSTEM MODELS. Annals of the University of Craiova, Economic Sciences Series, 3.

[7] Percic, S., Apostoaie, C. M., \& Cocris, V. (2013). EARLY WARNING SYSTEMS FOR FINANCIAL CRISES-A CRITICAL APPROACH. Centre for European Studies (CES) Working Papers, 5(1).

[8] Lind, D. A., Marchal, W. G., \& Wathen, S. A. (2012). Statistical techniques in business \& economics. McGraw-Hill/Irwin,.

[9] Shumway, R. H., \& Stoffer, D. S. (2011). Time series regression and exploratory data analysis. In Time series analysis and its applications (pp. 47-82). Springer New York.

[10] Quansah, J. E., Engel, B., \& Rochon, G. L. (2010). Early warning systems: a review. Journal of Terrestrial sObservation, 2(2), 5. 